\title{
USE OF WI-FI NETWORKS AMONG PRIMARY AND LOWER SECONDARY SCHOOLS
}

Václav ŠIMANDL*, Jihočeská univerzita v Č. Budějovicích, Česká republika Patrik KLOFAČ , Jihočeská univerzita v Č. Budějovicích, Česká republika

Přijato: 19. 6. 2017 / Akceptováno: 6. 8. 2017

Typ článku: Výzkumný článek

DOI: $10.5507 /$ jtie.2017.017

Abstract: The article looks at the ways lower secondary and primary school pupils and teachers in the Vysočina Region make use of Wi-Fi networks. Attention has been devoted to technical aspects of their implementation as well as to the various benefits and the possible complications that a chosen solution has brought. Our research has covered a wide range of schools that use Wi-Fi networks and make them accessible only for teachers or for teachers and pupils as well as schools that are not in possession of Wi-Fi networks. In-depth, semistructured interviews have been carried out with school headmasters and network managers. The results show that most of the interviewed schools use Wi-Fi networks to support teaching and learning. However, these networks are usually accessible for teachers only. According to our findings, schools in which at least some lessons are based on tablet and Internet use are quite rare.

Key words: Wi-Fi, mobile device, teaching, lower secondary school.

\section{VYUŽITÍ WI-FI SÍTÍ NA ZÁKLADNÍCH ŠKOLÁCH}

Abstrakt: Článek se zabývá využíváním Wi-Fi sití učiteli a př́padně žáky na základnich školách, které jsou tvořeny prvním i druhým stupněm, v rámci Kraje Vysočina. Pozornost je věnována nejen technickým aspektưm implementace, ale i prínosu a př́padným komplikacím, které s sebou dané rešeni přináši. Vyhledali jsme školy, které vlastni Wi-Fi sit' a zpřistup̌̌uji ji bud' jen učitelìm, nebo učitelům i žákům, a také školy, které Wi-Fi sit' nevlastní. S řediteli těchto škol a s osobami starajicimi se o chod počitačových sití těchto škol jsme realizovali hloubkové polostrukturované rozhovory. $Z$ výsledků vyplývá, že většina námi oslovených škol využivá Wi-Fi sitě v pedagogickém procesu, avšak přistup k síti maji obvykle jen učitelé. Školy, ve kterých by byla alespoň část výuky postavena na práci s tablety a použivání Internetu, jsou dle našich zjištěni výjimečné.

Klíčová slova: Wi-Fi, mobilní zařízení, výuka, základní škola.

\footnotetext{
*Autor pro korespondenci: simandl@pf.jcu.cz
} 


\section{1 Úvod}

Informační a komunikační technologie (ICT) procházejí v současné době značnou proměnou. Jak uvádí Neumajer (2013), trendem je přechod od tradičních počítačů k mobilním zařízením a tato tendence je zřejmá i ve školství. Kromě notebooků či ultrabooků se do školní praxe často dostávají mobilní zařízení, která jsou vybavena mobilními operačními systémy a která jsou reprezentována zejména tablety a „chytrými“ mobilními telefony. Ačkoliv tablety či „chytré“ mobilní telefony v edukačním procesu nemohou zcela nahradit stolní či přenosný počítač, jsou jeho vhodným doplňkem (Neumajer, Rohlíková, \& Zounek, 2015). Proto lze očekávat, že tradiční počítače ze škol zcela nevymizí, ale budou s tablety koexistovat a učitel se bude moci rozhodnout, jakou technologii k zamýšlenému účelu (např. didaktickému cíli) využije.

Mobilní zařízení mohou sloužit ve výuce nejen učitelům, ale i žákům (Neumajer, \& Růžičková, 2015). Tato zařízení je tedy možné chápat jako zařízení pro podporu výuky, kdy je využívá pouze učitel, nebo jako zařízení pro podporu učení se, kdy tato zařízení používají samotní žáci. V tomto ohledu bývá zmiňován př́istup 1:1, kdy každý žák dané třídy může pracovat s (alespoň) jedním mobilním zařízením (Neumajer, 2015; Chan et al., 2006). Přri využívání mobilních zařízení pro podporu žákova učení se lze kromě klasického zapůjčování školních zařízení žákům využít model BYOD, kdy žáci používají při výuce svá vlastní zařízení (Johnson et al., 2014). Ačkoliv je tento přístup pro školy výhodný vzhledem k absenci investic do nákupu a údržby mobilních zařízení, je potřeba zajistit správné fungování zařízení v rámci školní sítě a vyřešit bezpečnostní či licenční otázky (Neumajer, \& Růžičková, 2015).

Využívání tabletů či „chytrých“ mobilních telefonů ve výuce může být chápáno nejen jako prostředek pro zvýšení motivace žáků, zpestření či rozšíření výuky (Benediktová, 2017), ale i jako nástroj, který může změnit učitelův způsob práce v hodině, komunikaci se žáky, tvorbu př́íprav či vzdělávání sebe sama (Černý, 2015). Učiteli se tak např́íklad otevírá možnost využívat efektivně principů konektivistické výuky (Černý, 2015) a orientovat výuku více na žáka a jeho potřeby (Liu, Navarette, \& Wivagg, 2014). Využití těchto mobilních zařízení je možné napříč předměty; zahraniční studie se zabývají využitím v předmětech jako je první (rodný) a cizí jazyk, matematika, biologie, zeměpis, fyzika, chemie, dějepis či umění (Crompton, Burke, \& Gregory, 2017). V českém prostředí je sice nabídka vhodných aplikací poněkud užší, lze však nalézt aplikace určené pro podporu výuky českého jazyka, matematiky, prírodovědy, fyziky, cizích jazyků či výtvarné výchovy (Veřmiřovský, 2015; Válek, \& Sládek, 2016). Kromě specializovaných výukových aplikací je možné využívat též aplikací neurčených primárně pro výuku, jako jsou nástroje pro získávání informací, komunikaci či sdílení dat (Stárková, \& Rusek, 2014). Podle výzkumu Benediktové (2017) používají pro podporu výuky v českém prostředí tablety přibližně dvě pětiny učitelů a další sedmina by je sice chtěla využívat, avšak je nemá k dispozici.

Aby bylo možno mobilní zařízení při výuce plnohodnotně používat, je potřeba zajistit kvalitní př́istup z mobilních zařízení ke cloudovým službám, a tedy i Internetu obecně (Neumajer, 2014). Tento požadavek však není na řadě škol naplněn, nebot' jak uvádí Nagyová (2015), na počátku roku 2015 měla pouze každá šestá zkoumaná škola dostatečné technické vybavení pro použíání Internetu při výuce a problematické se zdá být především připojení mobilních zařízení do školní sítě. Na druhé straně se během našich výzkumů v terénu setkáváme se školami, ve kterých je Wi-Fi sít' dostupná. Nabízí se tak otázka, zda jsou tyto sítě vhodně dimenzovány, aby najednou obsloužily mobilní zařízení 
používané všemi žáky jedné třídy, a př́ípadně jak školy využívají potenciál, který tyto sítě pro výuku skýtají.

Cílem výzkumu je zmapovat nasazení Wi-Fi sítí na základních školách a jejich využití při výuce. Dílčími cíli je vyzkoumat, jaké jsou technické aspekty implementace školních Wi-Fi sítí, jakým způsobem a za jakým účelem jsou využívány, zda jsou př́stupné i žákům, a zjistit, jaká pozitiva či negativa s sebou zvolený př́stup přináśí.

\section{Použité metody}

Výzkum byl navržen a realizován jako kvalitativní, kdy bylo zkoumáno deset základních škol, tvořených prvním a druhým stupněm, $v$ rámci Kraje Vysočina. Tyto školy byly vybírány tak, aby bylo $\mathrm{v}$ rámci výzkumu nalezeno co nejširši spektrum různých prŕípadů z hlediska zkoumaného jevu. Jednotlivé školy byly voleny především na základě vlastnictví Wi-Fi sítě školou a dostupnosti této sítě pro různé skupiny uživatelů. Školy zařazované do výzkumu lze $\mathrm{z}$ tohoto pohledu rozdělit na tři základní skupiny: školy bez Wi-Fi sítě; školy s Wi-Fi sítí dostupnou jen pro učitele; školy s Wi-Fi sítí dostupnou pro učitele i pro žáky. Dalšími kritérii pro výběr školy byla velikost dané školy a velikost obce, v níž se daná škola nachází. Tato kritéria byla zvolena proto, aby nebyl výzkum zaměřen jen na školy určité velikosti či z obcí o určité velikosti a aby tak byla získána očekávaná šíre spektra různých př́padů. Stručná charakteristika škol zařazených do výzkumu je uvedena v Tabulce 1 .

\begin{tabular}{|l|c|c|c|c|}
\hline $\begin{array}{c}\text { Škola } \\
\text { číslo }\end{array}$ & $\begin{array}{c}\text { Vlastnictví } \\
\text { Wi-Fi sítě }\end{array}$ & $\begin{array}{c}\text { Dostupnost Wi-Fi } \\
\text { sítě pro }\end{array}$ & $\begin{array}{c}\text { Počet žáků } \\
\text { školy }\end{array}$ & $\begin{array}{c}\text { Počet obyvatel } \\
\text { obce }\end{array}$ \\
\hline 1 & Ano & Učitele a žáky & 669 & 10900 \\
\hline 2 & Ano & Učitele a žáky & 163 & 1700 \\
\hline 3 & Ano & Učitele & 600 & 4900 \\
\hline 4 & Ano & Učitele & 478 & 16100 \\
\hline 5 & Ano & Učitele & 477 & 16100 \\
\hline 6 & Ano & Učitele & 451 & 10900 \\
\hline 7 & Ano & Učitele & 331 & 16100 \\
\hline 8 & Ano & Učitele & 159 & 1800 \\
\hline 9 & Ano & Učitele & 132 & 1000 \\
\hline 10 & Ne & - & 508 & 16100 \\
\hline
\end{tabular}

Tab. č. 1: Školy zar̆azené do výzkumu.

Jako základní metoda sběru dat byl použit polostrukturovaný rozhovor. Osoby zahrnuté do výzkumu byli ředitelé vytipovaných základních škol a osoby starající se o chod počítačových sítí na těchto školách, zejména ICT koordinátoři a interní i externí správci počítačových sítí. Na osmi školách byl realizován rozhovor s ředitelem i osobou starající se o chod školní počítačové sítě; na zbylých dvou školách byl proveden pouze rozhovor s osobou starající se o chod sítě.

Na úvod setkání s každým účastníkem výzkumu v souladu s doporučeními, která uvádí Švaříček (2007), proběhlo představení výzkumníka a realizovaného projektu, ujištění o anonymitě, žádost o participaci na výzkumu a žádost o souhlas s nahráváním rozhovoru na diktafon. Následoval samotný rozhovor, vedený podle základní osnovy, která je tvořena 
tzv. hlavními otázkami (Švaříček, 2007) a která reflektuje vytčené výzkumné cíle. Dle potřeby bylo možno během rozhovoru vytvářet a pokládat tzv. navazující otázky, které podle Švaříčka (2007) dodávají rozhovoru hloubku.

Analýza dat byla založena na metodě otevřeného kódování, do nějž byl zahrnut princip konstantní komparace podle Šed’ové (2007). Analyzovaný text byl rozdělen na jednotky, jimž byl přidělen vhodný kód (Šed'ová, 2007), a takto vytvořené kódy byly seskupeny do kategorií podle vnitřní podobnosti (Strauss, \& Corbin, 1999). Vzniklé kategorie byly uspořádány do určité struktury a na jejím základě byl sestaven výsledný text, který je deskriptivním obrazem obsahu jednotlivých kategorií (Šed’ová, 2007) a který tvoří kapitolu Výsledky. Tento výsledný text je dokumentován autentickými výpověd’mi účastníků výzkumu, které jsou vždy uvedeny kurzívou v uvozovkách.

\section{Výsledky}

$\mathrm{Na}$ základě rozhovorů bylo identifikováno několik základních oblastí, které se k použivání Wi-Fi sítí váží. Mezi tyto oblasti patř́i vlastnictví Wi-Fi sítě a její využívání, důvody vedoucí ke zřízení Wi-Fi sítě, rozsah pokrytí budovy školy, dostupnost Wi-Fi sítě pro učitele a žáky, zabezpečení Wi-Fi sítě, problémy spojené s vlastnictvím či používáním Wi-Fi sítě, způsoby využití Wi-Fi sítě pro podporu výuky a učení se a vize do budoucna.

Vlastnictví Wi-Fi sítě a její využívání. Téměř všechny školy, které jsme v rámci výzkumu oslovili, vlastní Wi-Fi sít. Zatímco některé školy vlastní Wi-Fi poměrně krátce (např́klad jeden rok), jiné školy ji provozují výrazně déle (až deset let). Jedinou výjimkou je škola, kde prozatím Wi-Fi není, avšak kde se plánuje její zrrízení: „Je to otázka budoucnosti, chtěli bychom, aby to byla blizká budoucnost". Ačkoliv většina škol Wi-Fi sít' aktivně používá a plánuje ji použivat i v budoucnu: „Postupně začneme začleňovat WiFi do výuky“, našli jsme i př́pad školy, pro níž Wi-Fi sít’ ztratila význam: „Takže tu Wi-Fi je, ale prakticky už se nepouživáa. Důvodem je, že ji nahradila sít' Ethernet: „Ty Wi-Fi sítě tu jsou, protože se neodmontovaly, když jsme přšsli na kabel, ale zároveñ se ani nijak neudržuji“" a škola před mobilními zařízeními upřednostňuje klasické stolní počítače: „Šli jsme cestou mít více počítačových učeben s pevnými počitači a s počítačovými koutky ve třídách".

Důvody vedoucí ke zřízení Wi-Fi sítě. Důvody pro vytvoření Wi-Fi sítě se mezi školami liší. Poměrně častou příčinou je umožnění př́istupu ke školní síti uživatelům, kteř́ pracují s mobilními zařízeními: „(...) aby se mohli připojit ti, co maji notebooky a tablety“. Tento požadavek se netýká jen tabletů a mobilních telefonů, které obvykle jinak než přes Wi-Fi připojit nelze, ale vzhledem $\mathrm{k}$ mobilitě také notebooků: „(výhodou je) určitě mobilita pro učitele, že se prakticky připojí kdekoliv“. Tento názor nabývá na důležitosti v případě rozšíření školní sítě do míst, kam by zavedení klasického Ethernetu bylo problematické: „Chtěli jsme bezproblémové připojeni $k$ Internetu v každé třídě a byla to rekněme lacinějši varianta Internetu než sekání do zdi“. Zejména u škol, které vlastní WiFi již delší dobu, sloužila zpočátku Wi-Fi sít' jako základ školní počítačové sítě: „Ze začátku to (Wi-Fi) byla nutnost, protože ve škole nebyly žádný kabely, takže kvưli tomu, aby měli učitelé nějaké prípojeni k Internetu“.

$\mathrm{V}$ předchozím odstavci se zmiňujeme o potřebě připojení uživatelů pracujících s mobilními zařízeními. Těmito osobami mohou být pedagogové školy: „Cíl byl, že zasitujeme školu, aby to bylo vhodný pro využití učitelù, napřiklad notebooky do vyučováni“", ale také návštěvníci školy: „Škola je zapojena do mezinárodnich projektů 
a prece jenom se tady občas objeví cizinci, kteři (...) aby mohli být online“. Žádný z oslovených účastníků výzkumu však mezi těmito osobami nezmínil žáky školy.

Rozsah pokrytí Wi-Fi. Školy se v rozsahu pokrytí Wi-Fi sítí značně liší. Zatímco řada škol má pokrytou téměř celou budovu školy: „Ano, celou školu. První i druhý stupeň, včetně všech kabinetĩ a mistností. Akorát šatny asi nejsou pokryté", jiné školy mají pokrytou pouze určitou část budovy, typicky učebny 2. stupně: „Je to jenom na druhém stupni $v$ téhle budově $v$ podstatě ve dvou patrech". Některé školy však mají Wi-Fi sít' dostupnou jen ve velmi malém prostoru, jak dokládají následující citace: „(Pokrytí je) kolem sborovny a tady pár učeben" nebo „,...) dosáhne jen do určitých oblastí, napřiklad na první stupeñ “. Lze tak očekávat, že zatímco některé školy použivají přístupové body pro domácí použití s malým dosahem i výkonem, jiné investovaly do profesionální sítě, ve které je možný např́íklad roaming: „,...) jdu po škole a Wi-Fi signál se mi předáváa“.

Dostupnost Wi-Fi sítě pro učitele a žáky. Wi-Fi sít je na školách ve většině př́ípadů dostupná pouze učitelům, žáci k ní přístup nemají: „Využití je čistě pro učitele, protože nás nic netlači $k$ tomu, aby to bylo pro žáky". Zatímco na většině těchto škol jsme nezaznamenali žádná omezení týkající se využití Wi-Fi učiteli, jedna škola chápe Wi-Fi sít jako technologii určenou čistě k pracovním účelům: „Není to ani volně prístupný učitelüm, že by si na telefonu brouzdali celý den. Je to opravdu jenom na pracovní počitače“.

Během našeho zkoumání jsme nalezli i školy, které svým žákům př́stup k Wi-Fi síti umožňují. Wi-Fi sítě těchto škol mohou být rozděleny na dvě samostatné sítě (tj. sítě mající odlišná SSID) s různou cílovou skupinou uživatelů: „Je to oddělené na žákovskou a učitelskou, takže tam z hlediska bezpečnosti žáci nemaji př́stup“. Tím sice není vyřešeno fyzické oddělení sítí (zejména vzájemné rušení jednotlivých zařízení), ale sítě jsou odděleny logicky (např́iklad mohou zařízení $\mathrm{v}$ jednotlivých sítích $\mathrm{z}$ hlediska zabezpečení mít jiná př́stupová práva). Aby nedocházelo $\mathrm{k}$ narušování výuky nežádoucí činností žáků na Internetu, může být žákovská sít' dostupná pouze ve vymezeném čase, napríklad o přestávkách: „(...) je omezená časově, maji tam př́stup jen o přestávkách a odpoledních pauzách mimo vyučování, jinak ne“. Poznamenejme, že otázka zpř́ístupnění Wi-Fi sítě pro žáky je pro některé školy otevřená, jak diskutujeme dále v části textu Vize do budoucna.

Ačkoliv samotná škola nemusí žákủm umožnit př́stup ke své školní Wi-Fi síti, je možné, že žáci získají př́stup $\mathrm{k}$ Internetu jinými způsoby. Kromě připojení přes služby mobilního operátora jsme se setkali s př́kladem školy, $\mathrm{v}$ jejiž části byla př́stupná veřejná Wi-Fi sít”: „Wi-Fi zde funguje veřejná, placená městem, tam se dostane každý, i děti““.

Důvody odmítání př́ístupu žáků k Wi-Fi síti. Důvody, proč školy odmítají umožnit př́stup žákům, mohou být technologického či pedagogického rázu. Mezi technologické aspekty patří nízké maximální zatížení Wi-Fi sítě: „(...) protože by se ta sit' absolutně zhroutila" nebo problematické zabezpečení sítě ve smyslu zajištění odlišných př́ístupových práv učitelů a žáků. Mezi pedagogické aspekty patr̂́i nejen obava z narušování výuky: „Kdyby tu byl volný prístup $k$ Wi-Fi, tak dèti nebudou dèlat nic jiného, než že budou jenom $n a W i-F i^{“}$, ale také obava z př́lišné fixace žáků na život v online prostoru: „Neni horšsi pohled než na 30 dètí chodících po chodbách a koukajicich do mobilu" a z činností prováděných žáky v online prostoru: „(v ohledu) povědomí o nějaké etice a netice (myšleno netiketě) chování na síti (zpřistupnění) pro žáky nepřipadá v úvahu“. U některých účastníků výzkumu je zřejmý pocit minimálního př́nosu online technologií pro žáky: „Podle mé prínos volné Wi-Fi neni vủbec pro děti, není úplně nulový, ale má to mnohem víc záporư““, který může přecházet až ve skepsi týkající se používání Internetu žáky: „(...) 
to jsou závisláci, dneska jsou všichni závislí na svém mobilu. Matematiku umět nebudou, hlavně že maji mobil, opravdu to padá dolü“.

Zabezpečení Wi-Fi sítě je řešeno obvykle pomocí jednotného předsdíleného hesla. Toto heslo, pokud nemají mít do sítě přístup žáci, zná bud’ jen správce školní sítě: „Správce sitě zadal do všech školnich notebookủ heslo a nikdo jiný to heslo nevi", nebo (častěji) také vybraní učitelé školy. Na řadě škol došlo během času k odhalení tohoto hesla žáky: „Postřehl jsem, že dèti se (...) nějakým mně neznámým zpưsobem dostali k heslu“, načež obvykle následovala změna tohoto hesla: „tak ho zase změnime a je to" nebo přechod na jiný způsob zabezpečení sítě.

Některé školy používají pro zabezpečení Wi-Fi sítě pokročilejší metody. Mezi ně patří využití autentizačního RADIUS serveru, kdy má každý uživatel své vlastní přihlašovací údaje, nebo vytvoření seznamu povolených MAC adres, jimž je umožněno připojení do sítě: „Učitelská Wi-Fi se připojuje jenom přes fyzické adresy zařizení, které tady použiváme $k$ té $W i-F i^{“}$. Setkali jsme se i s př́kladem školy, která část rozsahu IP adres přiděluje staticky vybraným školním zařízením, čímž zaručuje jistotu príistupu těchto zařízení do sítě, a zbytek rozsahu IP adres ponechává $\mathrm{k}$ dispozici ostatním uživatelům: „my jsme si teda dali jakoby pevné IP adresy, oběhal jsem všechna školni zařizení a ted' tam jsou pevně nastavené, že teda maji prioritni prístup, pustí to teda i dalši zařizení (...)“.

Problémy spojené $\mathbf{s}$ Wi-Fi sítí se týkají především nedostatečného dimenzování sítě pro zamýšlené použití a (nežádoucího) připojování žáků do sítě. Nedostatečné dimenzování sítě se může projevit v nedostatečném pokrytí školy oproti očekávanému stavu: „Dosah té jedné wifiny nebyl tak velký, takže jsme nechali ještě jednu přiinstalovat" a prrípadně také v nedostatečném výkonu pro obsluhu většího množství zařízení: „Ted' je ten výkon sitěe, že se v každé třídě napojí bez problému tři až čtyř mašiny, pokud víc, tak se to začiná zahlcovat". Tato situace může nastat, pokud mají $\mathrm{k}$ síti legální př́stup i žáci: „co se týče té žákovské sitě, tak tam to často vypadávalo, bylo to přetižené“. Jestliže mají prrístup $\mathrm{k}$ síti pouze učitelé, není přetížení sítě prríliš časté; problém však nastává pří masivním proniknutí žákủ do sítě, naprííklad při zjištění předsdíleného hesla žáky: „(Žáci) nám zahltili sit', že se na to nabourávali, čili někdo se podřekl a oni nám zahltili DHCP“. $\mathrm{Z}$ tohoto hlediska se ukazuje jako nutnost důsledně oddělit sít pro učitele od sítě pro žáky (mají-li mít žáci k Wi-Fi síti př́stup) a řádně zabezpečit učitelskou sítě před potenciálním průnikem žáků do této sítě.

Zaměřme-li se na snahu žáků získat přístup $\mathrm{k}$ Wi-Fi síti, můžeme identifikovat několik možných způsobů získání předsdíleného hesla $\mathrm{k}$ síti. Mezi ně patří náhodné vyzrazení hesla učitelem, zjištění hesla z nastavení školních notebooků: „To heslo je napřiklad prístupné přes Windows 7, tam se jim to heslo zobrazi, takže nevíme, jestli se to heslo dostalo přes učitele nebo tímto zpưsobem“ nebo př́mé žádosti žákủ o sdělení hesla: „,...) hlavně osmáci otravuji a chtěji samozřejmě heslo“. Jestliže je heslo žáky zjištěno, žáci mezi sebou patřičnou informaci poměrně rychle šiří, at' už z nezištných důvodů či za úplatu: „Žáci dokonce heslo prodávali“. Školy nepovolené připojování žáků do sítě odmítají nejen kvůli riziku přetížení sítě (jak je diskutováno výše), ale i z „principu“, tedy protože je toto jednání zakázáno: „Problémy máme spís s tím, že nechceme, aby se děti prípojovaly, když nemaji“". Poznamenejme, že sekundárním problémem spojeným s průnikem žáků do sítě může být také záměrné narušování fungování (hacking) infrastruktury sítě: „Problém je občas, že žáci ovládaji přes mobilni zařizeni projektory, o to horši je, že to mohou dělat žáci klidně z jiné třídy". 
Využití Wi-Fi sítě v edukačním procesu lze rozdělit na dvě základní oblasti, a to používání Wi-Fi učitelem k výuce a používání Wi-Fi žáky k učení se. Využívání Wi-Fi sítě k podpoře žákova učení se není na školách př́liš rozšířeno - k tomuto účelu je Wi-Fi sít' používána pouze na jedné z námi oslovených škol. Zde je Wi-Fi technologie při výuce využívána žáky k získávání informací z Internetu: „,.... občas si vyhledávají informace na svých mobilech“. Jak je z citace zřejmé, škola spoléhá na model BYOD, kdy žáci využívají svá vlastní mobilní zařízení. Na jiné z oslovených škol mají sice někteří učitelé snahu WiFi pro podporu žákova učení se používat, avšak brání tomu administrativní problémy: „Já to nevyuživám, protože mi to zakázali, tam byl problém v tom, že my máme zaplacený určitý počet připojení (...) a ten limit jsme prekročili“ a technické problémy: „Ta veřejná Wi-Fi $v$ té tř́dě nefungovala tak, jakjsem chtěla. Třeba, když jsem jim řkekla, at' něco najdou, tak museli do rohu tř́dy a hledat tam (...)“. Na ostatních námi oslovených školách žáci Wi-Fi při výuce nepoužívají; důvodem obvykle je, že jim školní Wi-Fi sít' není př́ístupná (jak diskutujeme výše).

Využití školní Wi-Fi sítě učitelem k podpoře výuky je naopak realizováno na všech námi oslovených školách, které vlastní Wi-Fi sít'. Učitelé využívají Wi-Fi při přípravě výuky: „Určitě je větši a lepši př́stup $k$ materiáli̊m, že to nemusím připravovat doma a můžu to udělat tady“ i při samotné výuce (viz dále). Učitelům Wi-Fi připojení slouží jako alternativa ke klasickému Ethernetu. Přínosem je možnost využívat vlastní (obvykle svěřené školní) zařízení namísto stolního počítače a přitom být připojen do školní sítě a potažmo k Internetu: „Učitelé už třeba nevyuživají ten $P C$, co je zabudovaný v učebně, ale přinesou si svi̊j. Nemusí řešit kabely a vše krásně přes Wi-Fi se svými materiály“. Zároveň mají učitelé možnost mobility v rámci místnosti: „,...) byla by věčná škoda, kdyby se (notebooky) nemohly připojit všude a (učitelé) hledali, kde bude nějaká zásuvka nebo nějaký kabel, aby se mohli napojit".

Možnosti využití Wi-Fi sítě učiteli při vyučovací hodině jsou poměrně široké - školy oceňují zpřístupnění výukových materiálů z Internetu: „Většinou je to v hodinách, $k d e$ vyučujici má výukové materiály na Internetu“ nebo ze sít’ového disku v rámci školní sítě: „Primárně to slouži jako připojení učitelů do školni sítě, připojení notebooků a tabletů k Internetu (...)“. Učitelé mohou díky Wi-Fi též účinněji reagovat na dotazy žáků a patřičné informace vyhledat př́mo během výuky: „(...) pokud narazi na nějakou nesrovnalost, mohou se kdykoliv během hodiny diky zařizení podivat na Internet". Tuto činnost mohou případně přenechat i žákům, kteří dané informace mohou vyhledat sami: „Když narazíme na problém, tak ho vyřešime hned na místě a děti si vygooglej co potřebují, samozrejmě za dohledu vyučujicího". Setkali jsme se i s př́kladem školy využívající WiFi sít' i pro bezdrátové připojení učitelova zařízení (typicky notebooku) k interaktivní tabuli: „Máme interaktivní tabule, které jsou vlastně bezdrátově připojený s notebookama“.

Rozsah používání Wi-Fi sítě učiteli k podpoře výuky se mezi školami značně liší. Zatímco na některých školách využívá Wi-Fi sít' podle oslovených účastníků výzkumu většina učitelů, setkali jsme se s př́íkladem školy, kde Wi-Fi využívá velmi málo učitelů: „Zatím (je Wi-Fi při výuce využita) minimálně, asi takjedna desetina učiteli̊ (to využivá)““. Při učitelově rozhodování, zda používat při výuce Wi-Fi sít' může hrát roli např́íklad jeho věk: „Mladši učitelé určitě ano (použivaji Wi-Fi při výuce), ti starši, to je horší, to by se museli z donucení, takže ti ze staré školy na ten Internet nepůjdou (...)“.

Vize do budoucna se na jednotlivých školách liší. Zatímco na některých jsme žádné explicitní vize týkající se Wi-Fi neidentifikovali, jiné školy plánují rozššření stávajících 
Wi-Fi sítí z hlediska pokrytí: „V horizontu dvou let chceme, aby celá škola byla pokryta Wi-Fi siti" “. Nejčastější vizí podle oslovených účastníků je zpř́ístupnění Wi-Fi sítě pro žáky školy: „Chceme udèlat, aby (...) byly dvě sitě, že by byla učitelská a žákovskáa. Žáci by tak získali prístup $\mathrm{k}$ Internetu ve vymezeném čase pro aktivity dle svého uvážení: „(...) chce nastavit Wi-Fi přistupnou o prestávkách pro děti, aby mély př́stup k Internetu“. Školy nicméně pomocí zprrístupnění Wi-Fi pro žáky chtějí zejména podpořit proces žákova učení se: „Skrz ten telefon se žáci připoji třeba na kviz a ten přes telefon vyplni“".

$\mathrm{Z}$ našich zjištění vyplývá, že školy zatím nemají zcela jasné představy o způsobu využití Internetu při výuce, lze však očekávat, že jednotliví učitelé ve svých předmětech vhodné aktivity naleznou. Zatímco některé školy do budoucna uvažují o zrízzení tabletové učebny: „Uvažuji do budoucna něco takového pořidit. Myslel jsem určitě na ty tablety, které zapojíme do výuky", setkali jsme se i s př́kladem školy, která spíše uvažuje o modelu BYOD: „mám takovou vizi, že by jednou ty dèti použivaly svoje vlastni chytrý zařizeni““.

\section{Diskuze a závěr}

Realizovali jsme kvalitativní výzkum, který se zabýval využitím Wi-Fi sítí na základních školách v rámci Kraje Vysočina. Výsledky výzkumu ukazují, že většina námi oslovených škol má vybudovanou dostatečnou infrastrukturu Wi-Fi sítí pro podporu učitelovy výuky. Učitelé tedy mají na většině námi oslovených škol možnost využít Wi-Fi sít při př́pravě na výuku i při výuce samotné. Je však obvykle na uvážení každého učitele, zda bude tyto možnosti využívat či nikoliv. Tento př́stup je v souladu s doporučeními Chvála (2013), který tvrdí, že učitelům, kteří chtějí využívat tablety ve výuce, by to mělo být umožněno a je dobré je $\mathrm{v}$ tom podporovat. Jednorázové, rychlé a plošné zavedení tabletů do škol v ČR by však nebylo účelné (Chvál, 2013). Z našich výsledků vyplývá, že ochota využívat Wi-Fi sít při výuce patrně záleží na věku učitele, resp. na tom, zda je daný učitel tzv. digitální domorodec nebo digitální imigrant (podle Prensky, 2001).

Z hlediska využití Wi-Fi sítí pro podporu žákova učení je situace poněkud odlišná. Ačkoliv jsou někteří učitelé schopni a ochotni Wi-Fi technologii pro tento účel využívat, školy nejsou na realizaci tohoto druhu vzdělávání v řadě př́padů připraveny. Většina škol totiž neumožňuje (a některé do budoucna ani neplánují umožnit) svým žákům př́stup ke školní Wi-Fi síti a to ani mimo výuku. Důvodem pro toto rozhodnutí mohou být obtíže technického rázu, např́klad nedostatečná robustnost Wi-Fi sítě (Nagyová, 2015). V některých př́padech je toto rozhodnutí způsobeno neochotou škol zpř́stupnit Wi-Fi sít' žákům z pedagogických důvodů a to ani mimo vyučování. Pedagogické důvody, které způsobují odmítání př́istupu žáků ke školní Wi-Fi sítí, patrně souvisejí s obavami, které se týkají používání mobilních zařízení při výuce a které byly popsány např́iklad v (Benediktová, 2017; O’Bannon, \& Thomas, 2014).

Do budoucna lze očekávat, že řada škol bude budovat dostatečně robustní Wi-Fi sítě, které budou prrístupné i žákủm. S narůstajícím počtem uživatelů těchto sítí bude patrně nutné vyřešit i zvyšující se náročnost jejich správy (v současné době např́klad nedisponuje řada škol adekvátním řízením přístupu oprávněných uživatelů ke své Wi-Fi síti). V tomto ohledu by měla pomoci Strategie digitálního vzdělávání do roku 2020, která počítá s financováním profesionální správy digitální infrastruktury škol tak, aby se pedagogičtí pracovníci školy mohli soustředit na pedagogický proces (MŠMT, 2014).

Otázkou související s výzkumem je přenositelnost výsledků na další základní školy určitých parametrů. Jelikož cílem výzkumu bylo především zmapovat rozmanité způsoby využití Wi-Fi sítí na základních školách, identifikace vlivů, které školy ve způsobu 
využívání Wi-Fi sítí ovlivňují, byla spíše upozaděna. Proto nelze vyslovit např́iklad soudy ke způsobu využití Wi-Fi sítí na základě jejich velikosti či velikosti obce, ve které se nacházejí. Pestrost zkoumané reality a mnohdy nízkou vazbu na explicitně rozeznatelné okolnosti ostatně ukazuje srovnání př́stupu dvou podobně velkých škol z jednoho města k nelegálnímu připojování žáků do Wi-Fi sítě: „Některé děti se tam pořád dostanou (pripojí $k$ Wi-Fi síti), zatím to neřešime, zatím s tím nebyly problémy.“vs. „Vyzrazené heslo détem, to by bylo. To by byl únik, to by bylo strašný (...)“. Vlivem, který může školu vést $\mathrm{k}$ používání Wi-Fi sítí pro podporu žákova učení se, může být např́iklad přítomnost učitele, který takový typ výuky preferuje: „,Pokud se objevi někdo (nějaký učitel), kdo to bude chtít, tak ty penize se dřiv nebo později seženou a ta (tabletová) učebna se vybuduje“.

$\mathrm{V}$ dalších výzkumech se bude potřeba zaměřit na zjištění, do jaké míry je využivání Wi-Fi sítí a obecněji i mobilních zařízení ve výuce skutečně prospěšné pro žákovo učení se ve srovnání s klasickou výukou. Bylo by též potřeba zjistit, jaké důvody vedou školy ke skepsi vůči používání Wi-Fi sítí a potažmo mobilních zařízení žáky během výuky pro podporu jejich učení se.

\section{Literatura}

Benediktová, L. (2017). Využití tabletů z pohledu učitelů ZŠ. Journal of Technology and Information Education, 9(1), 5-14. doi: 10.5507/jtie.2016.025

Chan, T. W., Roschelle, J., Hsi, S., Kinshuk, K., Sharples, M., Brown, T., ... \& Soloway, E. (2006). One-to-one technology-enhanced learning: An opportunity for global research collaboration. Research and Practice in Technology Enhanced Learning, 1(1), 3-29. Dostupné z http://hal.univ-grenoblealpes.fr/file/index/docid/190632/filename/A132_Chan-et-al2006_OneToOne.pdf Crompton, H., Burke, D., \& Gregory, K. H. (2017). The use of mobile learning in PK-12 education: A systematic review. Computers \& Education, 110, 51-63. doi: 10.1016/j.compedu.2017.03.013

Černý, M. (2015). Tablet v rukou učitele. In M. Černý \& P. Mazáčová, et al., Tablet ve školní praxi (pp. 9-17). Brno: Masarykova univerzita. Dostupné z http://eknihy.knihovna.cz/static/files/tablet-ve-skolni-praxi.pdf Chvál, M. (2013). Flexibook 1 : 1: Zpracování výsledkủ doprovodného výzkumu. Dostupné $\mathrm{z}$ https://www.fraus.cz/file/edee/dokumenty-kestazeni/flexibook1_1_prezentace_martin_chval.pdf

Johnson, L., Adams Becker, S., Estrada, V., \& Freeman, A. (2014). NMC Horizon Report: 2014 K-12 Edition. Austin, Texas: The New Media Consortium. Dostupné z http://cdn.nmc.org/media/2014-nmc-horizon-report-k12-EN.pdf

Liu, M., Navarrete, C. C., \& Wivagg, J. (2014). Potentials of mobile technology for K-12 Education: An investigation of iPod touch use for English language learners in the United States. Educational Technology \& Society, 17(2), 115-126. Dostupné z http://www.ifets.info/journals/17_2/10.pdf

MSSMT (2014). Strategie digitálního vzdělávání do roku 2020. Dostupné z http://www.msmt.cz/uploads/DigiStrategie.pdf

Nagyová, I. (2015). ICT in Northern Moravia Elementary Schools. In Information and Communication Technology in Education. Proceedings (pp. 155-161). Ostrava: Ostravská univerzita, Pedagogická fakulta. Dostupné Z https://konference.osu.cz/icte/dokumenty/2015/proceedingsICTE2015.pdf 
Neumajer, O. (2013). Trendy ve vzdělávání s ICT v roce 2013. In Počítač ve škole 2013. Sborník přispěvků. Nové Město na Moravě: Gymnázium Vincence Makovského se sportovními tř́dami Nové Město na Moravě. Dostupné z http://www.pocitacveskole.cz/system/files/uzivatel/9/clanky/neumajer_pdf_26635.pdf Neumajer, O. (2014). Sedm mýtů o tabletech ve škole. In Metodický portál: Články. Dostupné z http://spomocnik.rvp.cz/clanek/18989/sedm-mytu-o-tabletech-ve-skole.html Neumajer, O. (2015). Diskuze o tabletech je potřebná, musí ale vycházet z objektivních dat. In Metodický portál: Články. Dostupné z http://spomocnik.rvp.cz/clanek/20183/diskuze-o-tabletech-je-potrebna-musi-alevychazet-z-objektivnich-dat.html

Neumajer, O., Rohlíková, L., \& Zounek, J. (2015). Učíme se s tabletem: Využití mobilních technologii ve vzdělávání. Praha: Wolters Kluwer, a. s.

Neumajer, O., \& Růžičková, D. (2015). Souhrnná zpráva projektu Vzděláváme pro budoucnost aneb Scénář využití mobilních dotykových zařizení s operačním systémem Windows ve školách. Microsoft. Dostupné $\mathrm{z}$ http://www.nuv.cz/uploads/Souhrnna_zprava_Vzdelavame_pro_budoucnost.pdf O'Bannon, B. W., \& Thomas, K. (2014). Teacher perceptions of using mobile phones in the classroom: Age matters!. Computers \& Education, 74, 15-25. doi: 10.1016/j.compedu.2014.01.006

Prensky, M. (2001). Digital natives, digital immigrants part 1. On the horizon, 9(5), 1-6. doi: $10.1108 / 10748120110424816$

Stárková, D., \& Rusek, M. (2014). Využití m-technologií v problémové, badatelské a projektové výuce. In M. Rusek, D. Stárková \& I. Metelková, Projektové vyučování $v$ prírodovědných préedmětech (pp. 85-91). Praha: Univerzita Karlova. Dostupné z http://pages.pedf.cuni.cz/pvch/files/2011/11/PBE2014.pdf

Strauss, A., \& Corbin, J. (1999). Základy kvalitativního výzkumu: Postupy a techniky metody zakotvené teorie. Boskovice: Albert.

Šed’ová, K. (2007). Analýza kvalitativních dat. In R. Švařǐček \& K. Šed’ová, et al., Kvalitativní výzkum v pedagogických védách (pp. 207-247). Praha: Portál.

Švaříček, R. (2007). Hloubkový rozhovor. In R. Švaříček \& K. Šed’ová, et al., Kvalitativní výzkum v pedagogických vědách (pp. 159-184). Praha: Portál.

Válek, J., \& Sládek, P. (2016). Mohou být mobilní technologie prostředkem pro výuku prírodovědných předmětů současné generace žáků? Journal of Technology and Information Education, 8(1), 73-83. doi: 10.5507/jtie.2016.004

Veřmiřovský, J. (2015). Výsledky průzkumu využívání tabletů na základních školách Moravskoslezského kraje. Media4u Magazine, 12(1), 9-12. Dostupné z http://www.media4u.cz/mm012015.pdf 